Chapter 3

\title{
Diversity of Neural Stem/Progenitor Populations: Varieties by Age, Regional Origin and Environment
}

\author{
Emília Madarász \\ Additional information is available at the end of the chapter \\ http://dx.doi.org/10.5772/55678
}

\section{Introduction}

Criteria of „neural stemness” characterize a large number of terminally non-differentiated neural tissue cells. Neural stem/progenitor cells capable for asymmetric mitoses (resulting in a similar and a differently committed daughter cell which may adopt neuronal or glial phenotypes in further development) are present during the entire life-span of vertebrates and have been found in almost all regions of the brain. With the advancement of neural tissue genesis and maturation, more and more stem/progenitor-like cells adopt "quiescent" states, but can be activated by appropriate (yet not properly understood) stimuli. Besides asymmetric (stem cell specific) division, these cells can multiply by symmetric mitoses resulting in identical progenies. Self-renewal and symmetric multiplication are responsible for maintaining or expanding stem/progenitor populations at the actual stage of neural commitment. Expanded pools of cells with similar, but yet flexible developmental potential can provide the desired number and type of cells for genesis, maintenance and repair of the nervous tissue. Except the ontogenetically and phylogenetically "oldest" pioneer and/or large projection-type neurons [1], the majority of neural tissue cells are produced through successive stem/progenitor stages [2]. The extreme cellular diversity of the mature CNS implies huge diversity in the precursor populations. Accordingly, a large number of neural stem/progenitor populations exist in different stages of neural cell fate commitment and display different cellular characteristics, developmental capability and flexibility. "Quiescent" and actively proliferating stem cells, transient amplifying progenitor populations and migrating or resident progenitor/precursor cells reside at various "niches" including the "professional" neurogenic zones, migratory routes and the neural parenchyma, as well. Drifts in cell biological features and differentiation potential of stem/progenitor/precursor cells are implemented by the advancement of development, by the position along the body axes and by the physiological or pathophysiological 
changes of the local environment including neighbouring cells, extracellular matrix, metabolite-, oxygen- and growth factor-supply and activity-driven ionic composition.

With improvement of methodologies, different populations of NS cells have been isolated, propagated and investigated in vitro. Despite of rapidly accumulating data, however, the similarities and differences among various NS populations are not properly understood either in vivo or in vitro. This chapter intends to give an insight in the intrinsic varieties of NSC populations. As examples, fairly distinct features of in vitro propagated early embryonic and adult-derived mouse neural stem/progenitor populations will be presented.

\section{Diversity of neural stem cells from early embryonic tissue genesis to adult-hood cell production}

\subsection{Neural stem cells in the neural plate and in primary geminative zones}

The earliest neural stem populations, the cylindrical neuroepithelial cells of the early embryonic neural plate (Fig.1) appear in the embryonic disc soon after embedding. As it was learned from studies on chick embryos, the anterior epiblast cells acquire "pre-neural" fate [3] as it is indicated by Sox 2 expression [4] under the influence of morphogen gradients established by two early organizers, the anterior visceral endoderm (AVE) [5] and the primitive streak and later by the node. The different morphogen concentrations result in different activation of positional (region-specific) genes, predestinating regions for different future fate in both chick and mammalian embryos [6,7] (Fig.1). Accordingly, despite of the apparent morphological homogeneity [8], neuroepithelial cells are not identical from the very beginning of neural tissue genesis.

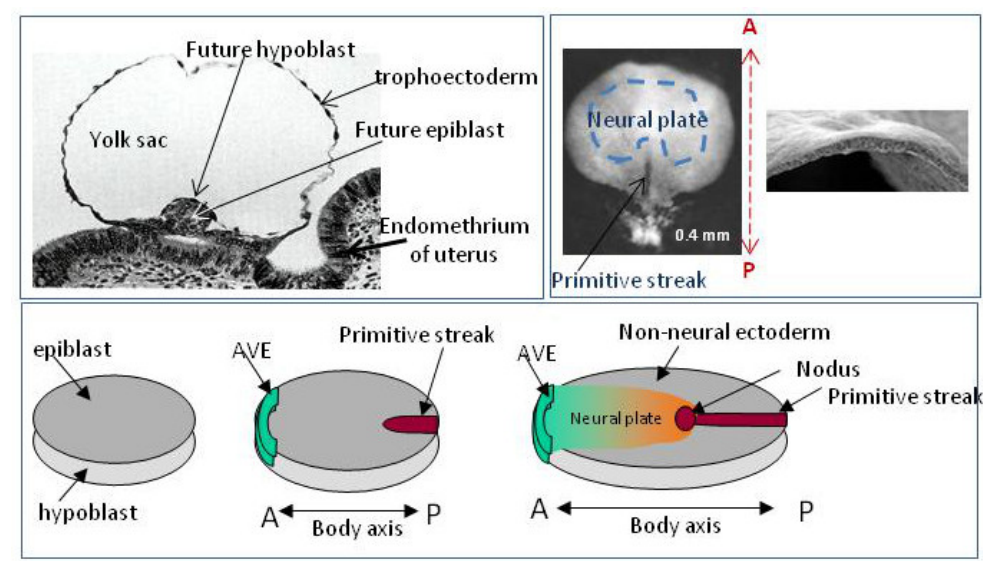

Figure 1. Scheme of formation and regionalization of the neural plate. The neural plate forms from the anterior epiblast in response to morphogens produced by the anterior visceral entoderm (AVE), the primitive streak and nodus 
and the non-neural ectodermal ridge of the epiblast. The positions along the anterior $(\mathrm{A})$ and posterior $(\mathrm{P})$ body axes imply regional differences among neuroectodermal cells.

During neural folding, a single layer of proliferating pre-neural stem cells called radial neuroepithel cells compose the neural plate and rapidly enlarge the neural primordium. These cells will give rise to primary neural stem cells, the embryonic radial glia (Fig.2), during the formation and closing of the neural tube (7-10 pcd in mouse). While the anterior cells of the epiblast of vertebrates were shown to generate neurons, if separated from their natural environment, ("default neural fate" [9]), or by blocking mesoderm-inducing morphogen actions, the mechanisms behind the transition of radial neuroepithel cells to radial glia cells are not properly understood.

Embryonic radial glial cells line the lumen of the neural tube in a single cell layer and compose the primary neural germinative zone (ventricular zone; VZ). The first neurons are generated in this layer by asymmetric mitoses of radial glial cells (Fig.2). Such division produces a daughter cell, which preserves radial glia characteristics and another one, a neuronal precursor, which looses proliferation capability and migrates outward from the lumen along a radial glia neighbour [10]. These early neuronal precursors will develop mainly to large, projecting type neurons [1]. Immediate cell-to cell interactions including Notch/Delta signalling [11] and growth factor - receptor signals (as neuregulin - ErbB; [12]) play inevitable roles in the determination and maintenance of asymmetric commitment of the two daughter cells.

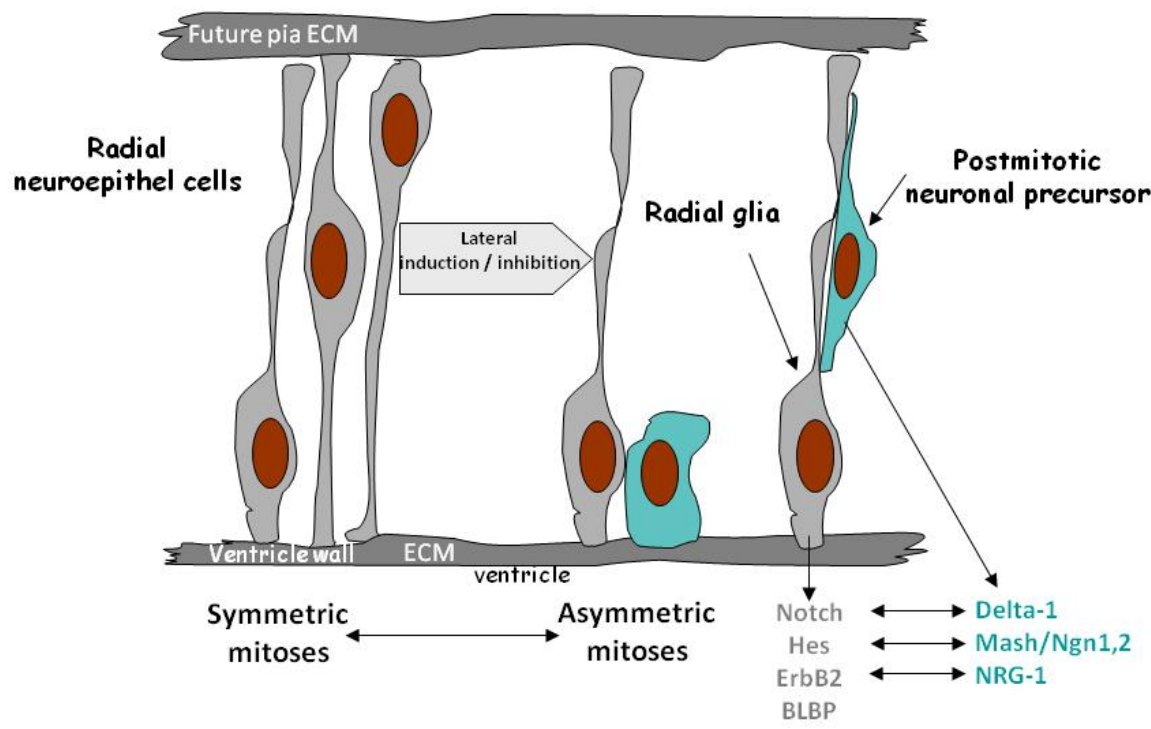

Figure 2. Formation of the primary neurogenic zone from radial neuroepithelial cells and generation of the first postmitotic neuronal precursors by asymmetric division of radial glial cells in the ventricular zone. 
The early radial glial cells express several "marker" features (Table 1), which together with cell shape and localization may identify them. In contrast to later neural stem/progenitor populations, radial neuroepithelial and early radial glial cells express Oct4 and nanog embryonic stem cell genes and the anterior epiblast-characterizing Otx2 and En1,2 "positional" genes (see ref. in Table 1). These cells span the whole thickness of the early neural tube, and can divide without changing their spanned shape [8].

These early neural stem cells proliferate rapidly (with cycle time of about 14-16 hours), but not continuously, and with both symmetric and asymmetric divisions. The symmetric mitoses assure the expansion and maintenance of neural stem populations at the given stage of commitment. Intermittent non-mitotic periods help the attachment and out-migration of neuronal precursors. During the formation and closure of the tube, the neural primordium is composed by a single neurogenic zone, but with heterogeneous cellular constituents [13] comprising asymmetrically and symmetrically dividing stem/progenitor cells, and migrating, differentiating neuronal precursors.

The cellular diversity of the early neural tube is further enhanced by the time-delay in development along the anterior - posterior and dorso-ventral body axes. The tube formation and closure proceed with a delay from the zone of brachial arches (the region for future hind brain) to both, rostral and caudal directions, and the production and maturation of neural cells on the ventral face always precede those on the dorsal part in each neural domain [14]. It means that even small samples of the tissue will contain diverse populations of (stem/amplifying/ differentiating) neural cells.

The cellular heterogeneity is further increased by the ongoing regional specification, which results in well-distinguishable domains with characteristic gene expression patterns along both the anterio-posterior and dorso-ventral axes of the growing CNS [28, 29]. Differential expression of positional master genes results in diverging expression patterns of "down-hill" genes including those coding for adhesion receptors and extracellular matrix proteins, and leads to the formation of morphological boundaries between the expression domains: the developing CNS is composed by segments called neuromeres [7,30]. Along the A-P body axis, transversal segments will delineate primary brain vesicles (prosencephalon, mesencephalon, rhombencephalon) first, and smaller neuromeres later on. Inside the larger segment boundaries, smaller developmental / morphological entities will develop as the prosomeres in the telencephalon or rhombomeres in the hindbrain. In parallel with the anterior-posterior segmentation, dorso-ventral specification will identify longitudinal domains in the developing CNS. Dorso-ventral specification is initiated by the early lateral-medial determination of the neural plate, namely, the midline expression of sonic hedgehog and the lateral expression of bone morphogenic (BMP) proteins (Fig.3). With tube formation, progenies of midline plate cells become the ventral-most tube cells composing the notoplate. Derivatives of lateral-most neural plate cells will compose the neural crest and the closing dorsal lip of the tube, the later roof plate. Notoplate cells produce Sh, while roof plate cells produce BMPs and Wnt morphogenic factors, establishing dorso-ventral morphogen gradients throughout the developing CNS (for a recent review: [31]). 


\begin{tabular}{|c|c|c|}
\hline & „Marker" features & References \\
\hline cell shape & $\begin{array}{l}\text { Elongated, bipolar shape; Adherent junctions at the lumen-face; laminin } \\
\text { receptors at the apical and basal ends; }\end{array}$ & {$[10,8]$} \\
\hline cellular motion & $\begin{array}{l}\text { interkinetic nuclear migration; mitotic nuclei at the lumen face; cell division } \\
\text { with spanned shape }\end{array}$ & {$[15,8]$} \\
\hline \multirow{4}{*}{$\begin{array}{l}\text { intermediate } \\
\text { filament proteins }\end{array}$} & vimentin (characterizes many non-differentiated cells) & \multirow{4}{*}{ [refs in 1] } \\
\hline & $\begin{array}{l}\text { GFAP (characterizes astrocytes; expression by radial glia cells is species- } \\
\text { dependent ) }\end{array}$ & \\
\hline & nestin (expressed by many progenitor-type cells including muscle progenitors) & \\
\hline & RC $(1,2)$ nestin-associated protein-epitope; radial glia marker in the CNS & \\
\hline \multirow{6}{*}{$\begin{array}{l}\text { master-gene } \\
\text { expression }\end{array}$} & $\begin{array}{l}\text { Oct3/4, nanog (embryonic stem cell/pluripotency genes; expressed in the } \\
\text { epiblast and sporadically in the forming neural plate) }\end{array}$ & [16] \\
\hline & $\begin{array}{l}\text { Otx2 (anterior positional gene; expressed in the anterior epiblast and in the } \\
\text { neural plate; later restricted to the forebrain regions) }\end{array}$ & {$[17,18]$} \\
\hline & $\begin{array}{l}\text { En1,2 (engrailed positional gene; expressed in the anterior epiblast, in the } \\
\text { neural plate; later restricted to isthmus and mesencephalic, cerebellar areas) }\end{array}$ & {$[19,20]$} \\
\hline & $\begin{array}{l}\text { Sox2 (codes for a HMG box transcription factor; expressed generally by CNS } \\
\text { neural stem cells) }\end{array}$ & {$[4,21,22]$} \\
\hline & $\begin{array}{l}\text { Pax6 (codes for a paired-box transcription factor; plays important roles in CNS } \\
\text { patterning and eye development; expressed by multiple neural stem/ } \\
\text { progenitor cells) }\end{array}$ & {$[23,24]$} \\
\hline & $\begin{array}{l}\text { Hes1,3,5 (code for a basic helix-loop-helix transcription factor repressing tissue- } \\
\text { specific cell differentiation) }\end{array}$ & [25] \\
\hline \multirow{3}{*}{$\begin{array}{l}\text { Cell surface } \\
\text { receptors and } \\
\text { transporters }\end{array}$} & $\begin{array}{l}\text { Notch1,3 (protein product: cell surface receptor with cleavable intracellular } \\
\text { transcription fragment (NICD) }\end{array}$ & [11] \\
\hline & ErbB (Neuregulin Trk receptor); & {$[12]$} \\
\hline & GLAST (Glutamate-aspartate transporter; astrocytes also express) & [26] \\
\hline $\begin{array}{l}\text { Intracellular } \\
\text { transporter }\end{array}$ & $\begin{array}{l}\text { BLBP (brain lipid binding protein; Intracellar transporter of hydrophobic } \\
\text { molecules including small nuclear ligand molecules) }\end{array}$ & [27] \\
\hline
\end{tabular}

Table 1. Radial glia "marker" features for characterization of radial glial cells 

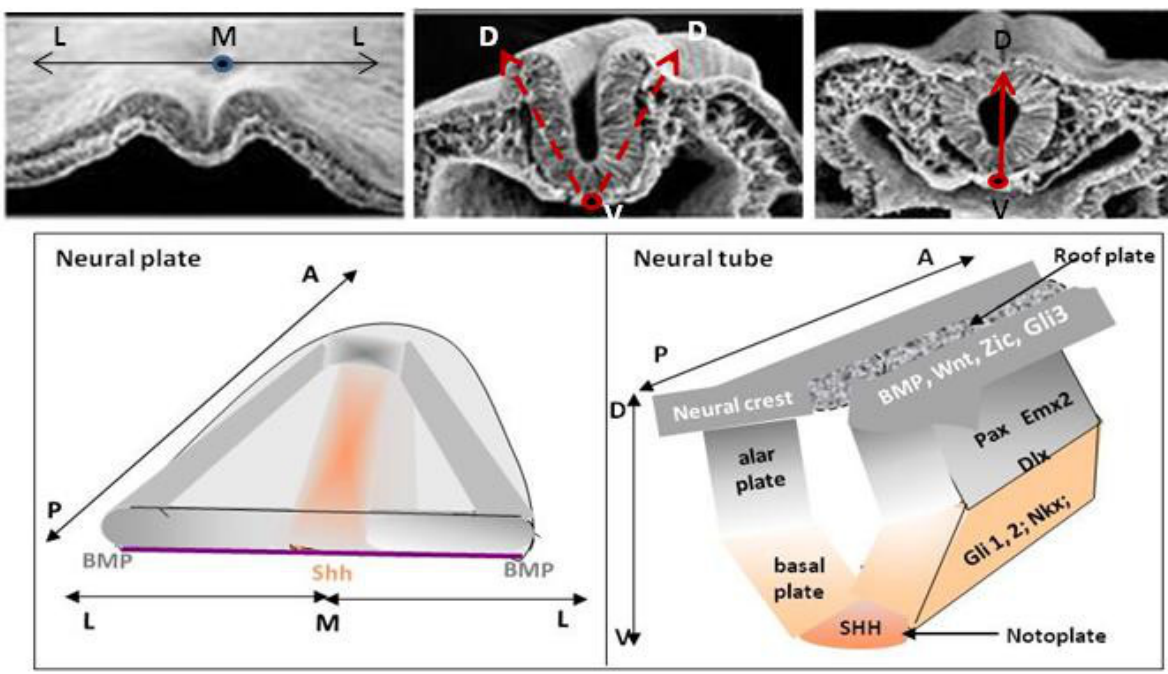

Figure 3. Schematic presentation of the establishment of dorso-ventral specification (longitudinal segmentation) in the neural tube. The lateral-medial (L-M) regionalization turns into dorso-ventral (D-V) regionalization when the neural plate folds and forms the neural tube. BMP: bone morphogenic proteins; SHH: sonic hedgehog protein; Zic, Gli-3, Pax6, Emx2, Dlx, Nkx are examples of genes expressed in different dorso-ventral domains.

The position along the antero-posterior and dorso-ventral axes determines the identity of future brain regions and seems to predict the phenotype of neurons through the orchestrated expression of defined region-specific, pro-neural and neuron-specific genes [28]. Boundaries between embryonic segments provide routes for the elongation of pioneer axons and delineate the paths for future fiber tracks.

For the time being, it is not clear whether the early embryonic position can (or how far can) determine the intrinsic developmental potential of individual cells. There are contradictory results on the "positional memory" of stem/progenitor cells if removed from their original position [32]. Our own data [33] indicate that neural stem-like cells isolated from early embryonic (E9) mouse forebrain do not display regional "memory" after in vitro propagation. In the course of in vitro neuron formation they express divergent region-specific genes, those not expressed in overlapping regions of the developing CNS. The data suggest that permanent presence of region-specifying factors is required for maintaining regional commitment, at least in case of early embryonic neural stem cells. This finding, however, does not compromise the fact that in vivo, neural stem/progenitor cells of the primary germinative (VZ) zone display important molecular and cell biological differences.

\subsection{Diversity of stem/progenitor cells in the secondary germinative zones of the developing brain}

With the thickening of the neural wall, increasing number of proliferation-capable cells loose contact either with the lumen-face (outer progenitors; OSVZ progenitors) or the pial surface 
(short progenitors; SNPs) or both (inner progenitors; ISVZ progenitors), and accordingly, change morphology and developmental characteristics [34,8]. The number of primary radial glial cells decreases gradually, while their derivatives dividing at a distance from the luminar surface generate a novel germinative zone, the subventricular zone (SVZ). While a few SNP cells remain in contact with the luminar surface and thought to preserve "ancient" (primary) stem cell properties, the layer lining the ventricle wall transforms to the future ependyma and neural cell production is transposed to the secondary germinative layer, the SVZ. The SVZs along the entire neuraxis generate large number of progenitors and precursors including smaller projecting-type neurons, interneurons, astrocytes, oligodendrocytes and produces also enough stem cells to maintain an appropriate neurogenic capacity (for review see [1]). Novel precursors migrate from the SVZs to final destinations along defined routes in the developing neural parenchyma. While the lineage relations among different SVZ progenitors are not fully explored [8, 35], it is clear that evolutionary new SVZ progenitors provide the cell generating capacity for the enlarged interneuron and glia populations of the avian and mammalian CNS and provide cell-pools for the enormous expansion of the cerebellar cortex and the mammalian forebrain. With the appearance of SVZs, the developing CNS comprises a large variety of coexisting neural stem/progenitor cells both, in multiple neurogenic zones and inside / around the cell migratory routes.

While secondary (SVZ) germinative zones form all along the wall of brain ventricles and the spinal canal, the time of formation and the cell productivity of these zones are not uniform along the neuraxis. At most parts of the developing CNS, SVZs generate neuronal and glial precursors for local tissues, and the cell-generating activity decreases with the maturation of the local neural parenchyma. Such zones, still containing "resting" stem/progenitor cells, can restore cell-generating activity in response to tissue loss or specific (not yet properly understood) physiological/pathophysiological stimuli. The most productive secondary germinative zones, including the ventral forebrain SVZ [36], the external germinative layer (EGL) of the cerebellum [37] and the subgranular zone (SGZ) of the hippocampus [38], however, generate huge amounts of novel neural cells and function for a relatively long time, in case of the ventral forebrain SVZ and the SGZ, for the entire life-time.

The SVZ at the latero-ventral wall of the forebrain vesicles forms in a relatively early period (second embryonic week in mouse) of forebrain development [36]. It derives from the primary germinative (VZ) zone of the highly regionalized subpallial ganglionic eminences (LGE, MGE and CGE,) [39]. The enhanced cell production with preserved regional characteristics results in the formation of a variety of neuronal progenitors/precursors for developing subcortical and cortical tissue formations [39]. This zone generates neurons for the striatum and globus pallidus, provides the vast majority of interneurons of the cortex [40,41], produces small connecting neurons for the ventral amygdala complex $[42,43]$ and, exclusively in humans, also for the dorsal thalamus [44]. Large number of forebrain oligodendrocytes also derives from the ventral SVZ complex $[45,46]$.

In contrast to the early appearance of the ventral forebrain SVZ, the external germinative layer (EGL) of the cerebellum appears around birth [47]. Secondary stem/progenitor cells from the dorsal lip of the $\mathrm{IV}^{\text {th }}$ ventricle migrate on the top of developing Purkinje cells, and produce 
basket and stellar neurons and billiards of cerebellar granule cells [37] for the cerebellar cortex. The third "professional" secondary neurogenic zone of the mammalian brain is the subgranular zone (SGZ) of the hippocampus [38], which derives from the ventricular (primary germinative) zone of the most dorsal forebrain structure, the hem [48, 49]. In addition to astrocytes and oligodendrocytes, SGZ produces a single type of projecting neurons, the granule cells of the dentate gyrus.

\subsection{Neural stem/progenitor cells in the adult mammalian brain}

At most sites, the subventricular zones cease producing neurons and reduce their gliaproduction after a short postnatal period of normal development, except the external germinative layer (EGL) of the cerebellum, where cerebellar granule cells are generated for at least 10 days after birth in mouse and 1-2 years in human [47], the SVZ of the ventral forebrain [50] and SGZ of the hippocampus [51], where neuro- and gliogenic capacity is maintained for the entire life-time. The adult SVZ generates neuronal precursors mainly for regularly remodelling forebrain circuits, as the higher voice centre of singing birds [52] or the olfactory bulb in rodents [53]. Incorporation of adult SVZ-derived novel neurons, however, had been reported also in the neocortex, piriform cortex, olfactory tubercle and amygdala in rodents and in primates, as well $[42,43,54,55]$. In contrast to the SVZ, available data indicate that SGZ produces precursors solely to the dentate gyrus. Both, the SVZ [46] and the SGZ [51, 56], however, contain consecutive descendent populations of progenitor cells, which seem to mutually regulate each other's generation [57].

The routes of migration and integration of newly generated "adult" neuronal precursors into olfactory and hippocampal networks have been explored in many details [51, 53, 58, 59, 60], and the exploration has been highly facilitated by the use of multiple transgenic reporter mouse straits (reviewed in [35]). Novel neurons are integrated by functioning neuronal networks and tune the physiological parameters of functional circuits in both, the olfactory bulb [61] and the hippocampus $[59,60]$. As it is widely accepted, continuous neurogenesis in the adult SVZ and SGZ plays organic roles in the physiological performance of the olfactory bulb and the hippocampus of mammals. In case of SVZ-derived precursors, however, further studies should explore the mechanisms behind the detachment of novel progenitors from the common migratory paths and the acquirement of different mature phenotypes.

Outside of adult neurogenic zones and migratory routes, developing novel neurons have been described in many regions of the adult brain, both in rodents (for ref. see [62]) and primates [54]. Local neuron formation was found at the striatum [63], hypothalamus [64], associate cortex [54, 65], ventral forebrain [43] and the substantia nigra of the midbrain (for review see [66]. Beside sporadic neuron formation, ongoing astroglia production and low-rate but permanent oligodendroglia replacement [67] also indicate that differentiation-capable neural stem/progenitor cells are scattered throughout the adult nervous tissue. Many of these progenitors might derive from continuously active ("professional") adult neurogenic zones [1, 45]. Quiescent cells with stem/progenitor capabilities however are present in the wall of brain ventricles and spinal canal [68] along the entire neuraxis, in large fibre bundles $[69,70]$ and in the functioning CNS parenchyma [71], as well. In response to stimuli, many quiescent tissue- 
resident neural cells can re-enter the cell cycle [72], can renew themselves and generate different - more than one - types of mature neural cells in vivo [69, 71, 73].

While such cells are regarded as neural stem cells according to „neural stemness" criteria, the time of birth, the route of migration, the conditions for settlement and quiescence are far from clear. The multiplicity of CNS derived stem/progenitor cells has been indicated also by the diversity of neural stem/progenitor cells investigated in vitro [74]; the data argue for a massive presence of tissue-resident neural cells with "stemness" properties throughout the CNS. To find single scattered quiescent cells in the healthy brain tissue or to determine their lineage relations are hard tasks, even with the use of transgenic reporter mice [35]. These neural stem / progenitor cells may have different origin, may represent different stages of neural cell differentiation and may adopt different cell physiological characteristics depending on the host environment. As they serve as resident progenitor pools for tissue repair and limited remodelling, it is of primary importance to explore their physiological characteristics and environmental requirements in order to understand local neural tissue reactions to physiological stimuli and various pathophysiological effects.

\section{Neural stem cells in vitro: Experimental data on diverse clones}

In vivo lineage analyses can hardly determine whether divergent fate decision could be made by a single cell or diversity was resulted by selective interactions inside a group of mixed cells [75]. Sophisticated cell isolation/propagation methods helped to prove the existence of multipotent neural stem cells. In vitro studies can describe neural stem cell features appearing under artificial conditions and can predict the potential phenotypes which can be acquired by the investigated cells. The in vivo fate and the phenotype manifested under in vivo conditions, however, can not be forecasted from in vitro data. For the time being, our knowledge on local microenvironmental factors governing the fate of differentiating neural cells or our understanding on characteristics and cell physiological requirements of differentiating cells do not allow extrapolating in vitro data to in vivo cell fates.

Neural stem/progenitor cells had been isolated and investigated in many laboratories using different methods and divergent source materials including developing or adult brain tissues and embryonic stem (ES) cells. Excellent recent reviews summarize the collected data including the expression of various gene clusters, the inducibility of different neuronal phenotypes and the growth factor requirements of various neural stem/progenitor preparations (for a recent review see [76]). Recent knowledge on differentiation-dependent changes in requirements for $\mathrm{O}_{2}$ and adhesive environment has been also summarized [77]. The diverse experimental approaches, however, hinder comparative characterization of neural stem/progenitor populations derived from different CNS regions and developmental ages.

Based on more than 10 different neural stem cell clones isolated and characterized in our laboratory, this chapter presents a comparative summary on important differences displayed by one-cell derived neural stem cell populations isolated from different ages and/or from different regions of the mouse brain. 


\subsection{Lessons from primary brain cell cultures}

From the middle of the last century, "primary" neural cell cultures gave a statistical insight into the cellular composition of many studied brain area and gained high importance in understanding the cellular characteristics of neural tissue constituents. It became clear that neuron-enriched cultures can be easily initiated from early stages of development (embryonic brain material), while tissue samples from later stages of brain maturation provide mainly glial cultures.

As terminally differentiated neurons and oligodendrocytes do not divide and display poor regeneration potential, primary neural cell cultures gave a hint on the presence and distribution of non-differentiated cells in the brain tissue, which served as precursors for the majority of cultured neurons and oligodendroglia cells. The in vitro preservation of many neuronal characteristics of the source region including the size, shape, neurotransmitter phenotypes and specific vulnerability of neurons [78] indicates either a relatively stable fate commitment of in vitro surviving progenitors/precursors or continued production of factors, which help to maintain some region-specific features.

In case of astrocytes, usually identified solely by GFAP expression, it was clear that in vitro propagation results in a "juvenile", "de-differentiated" phenotype, fairly distinct from in vivo astroglial cells [79]. In purified (90-95\% GFAP-positive) mouse astroglial cultures many cells express nestin, and a few of them express also SSEA-1 stem cell antigen (Fig.4). After longer (2 -3 weeks) propagation, "epithel dome"-like structures of rapidly dividing cells and GFAPnegative process-bearing O2A bipotential glial progenitor cells [69] often appear in purified astroglial cultures (Fig.4) [80,81].

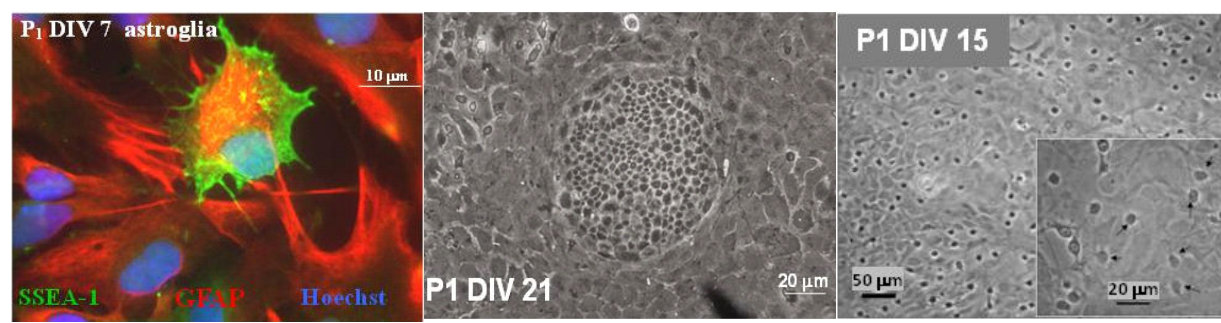

Figure 4. Non-differentiated cells in purified cultures of newborn (P1) mouse forebrain astroglial cells. Left: a SSEA-1 and GFAP double-immureactive cell on the $7^{\text {th }}$ day in vitro. Middle: an "epithel dome"-like cellular expansion on the $21^{\text {st }}$ day in vitro. Right: O2A-type progenitor cells in a 15-day old hypothalamic astrocyte culture.

As long-term propagation selects for rapidly proliferating cells, the size of such populations can be enlarged and one-cell derived clones may also emerge from such cells. Proliferation-based cloning from long-term propagated cultures, however, favours the selection for tumorigen, transformed cells and also, hinders the identification of in vivo origin of selected cells.

If primary neural cultures are prepared form early embryonic (E9-12 mouse) forebrain vesicles, clusters of rapidly proliferating non-differentiated cells occur with high frequency. From early 
embryonic source tissue, the larger frequency and rapid proliferation of non-differentiated cells allow isolating "almost primary" neural stem/progenitor cells after short-term in vitro propagation. Using the "serial splitting" method [82], we established and cloned various neural stem cell lines from E9-E11.5 mouse forebrain vesicles from, both, p53--- [83] and wild-type embryos.

While non-differentiated cells from the early embryonic (E9-12) brain attach readily to polyL-lysine or collagen coated surfaces in the presence of serum, cells isolated from more developed (E14-15) mouse forebrain form aggregates under such conditions indicating that the surface of neighbouring cells provide better adherence than the provided artificial surface. The majority of cells exist inside the aggregates (e.g. in completely unknown microenvironments), for a 2-3 day period before large-scale migration starts from the aggregates.

Rapid attachment of freshly seeded cells from "older" forebrain suspensions was achieved, if pre-patterned integrin-ligands were provided as adherent surfaces. Brush-like peptideconjugates built on a poly-L-lysine backbone and carrying rigid integrin-ligands (cyclic RGDfC pentapeptides) at the N-termini of regularly spaced poly-D/L lanine "spacer" side-chains (AK$\mathrm{c}$ [RGDfC]) [84] proved to support the attachment and serum-free propagation of a number of non-differentiated cells including mouse and human ES cells (manuscript in preparation). As neurons do not attach to the peptide-coated surface and differentiated glial cells do not proliferate in serum-free conditions, non-differentiated cells of brain cell suspensions could be selectively propagated under serum-free conditions on the peptide-coated surface (Fig.5). From forebrain suspension of transgenic mouse embryos (E14.5) carrying the human GFAPpromoter-driven GFP construct [85], GFP-labelled but GFAP-negative cells grew rapidly on AK-c(RGDfC)-coated surfaces indicating that the surface-attached populations comprised neural progenitor-type cells (Fig.5) [74].

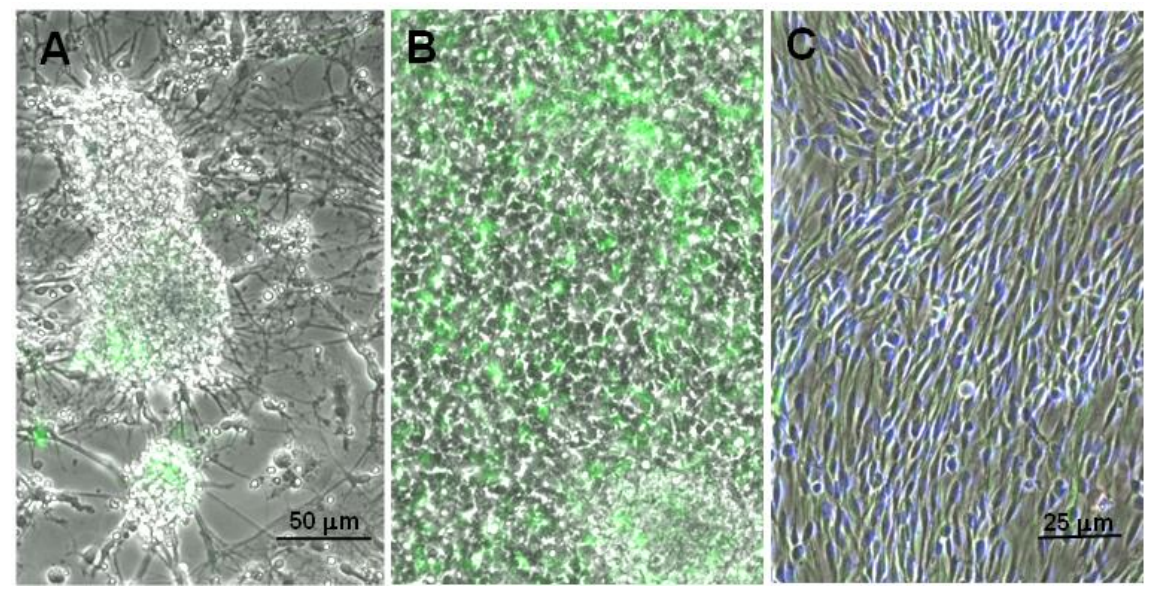

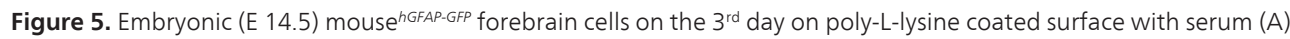
and on $A K-c(R G D f C)$ coated surface without serum (B). After two passages on AK-c(RGDfC) sureum and in serum-free conditions, the cultures were composed by GFP-expressing morphologically homogeneous, surface-attached cells (C). 
The "selective adhesion and serum free propagation" method allowed isolating and cloning cell lines from various parts of the embryonic (E 14-15) and adult (P50-75) mouse brains (Table 2).

\subsection{Comparative characterization of neural stem/progenitor clones}

Our first neural stem cell clones (NE-4C [ATTC CRL 2925] and NE-7C2) were established 15 years ago, from early embryonic (E9) anterior brain vesicles of p53-deficient mouse embryos $[82,86]$. The lack of p53 tumour suppressor protein did not prevent the in vitro formation of postmitotic neuronal precursors and later neurons [82], as did not hinder normal neural development of transgenic animals despite of increased tumour frequency in aging animals [83]. For control, however, similar cell lines had been established from wild-type mouse embryos (WNE cell lines) and were proved to display similar characteristics including morphology, chromosome-stability, cell cycle-time, regional gene expression and the schedule of in vitro neuron and glia formation. NE-4C, NE-7C2 and WNE cells showed similarities to P19 EC and embryoid body-derived ES cells in many aspects [33,87], and showed marked differences if compared to AK-c(RGDfC) adherent stem/progenitor cells isolated either from late embryonic or adult brain regions (Table 2). All clones shown on Table 2 can be propagated in vitro without differentiation or changing phenotype, and can generate neurons, astrocytes and oligodendrocytes in response to appropriate inducing stimuli.

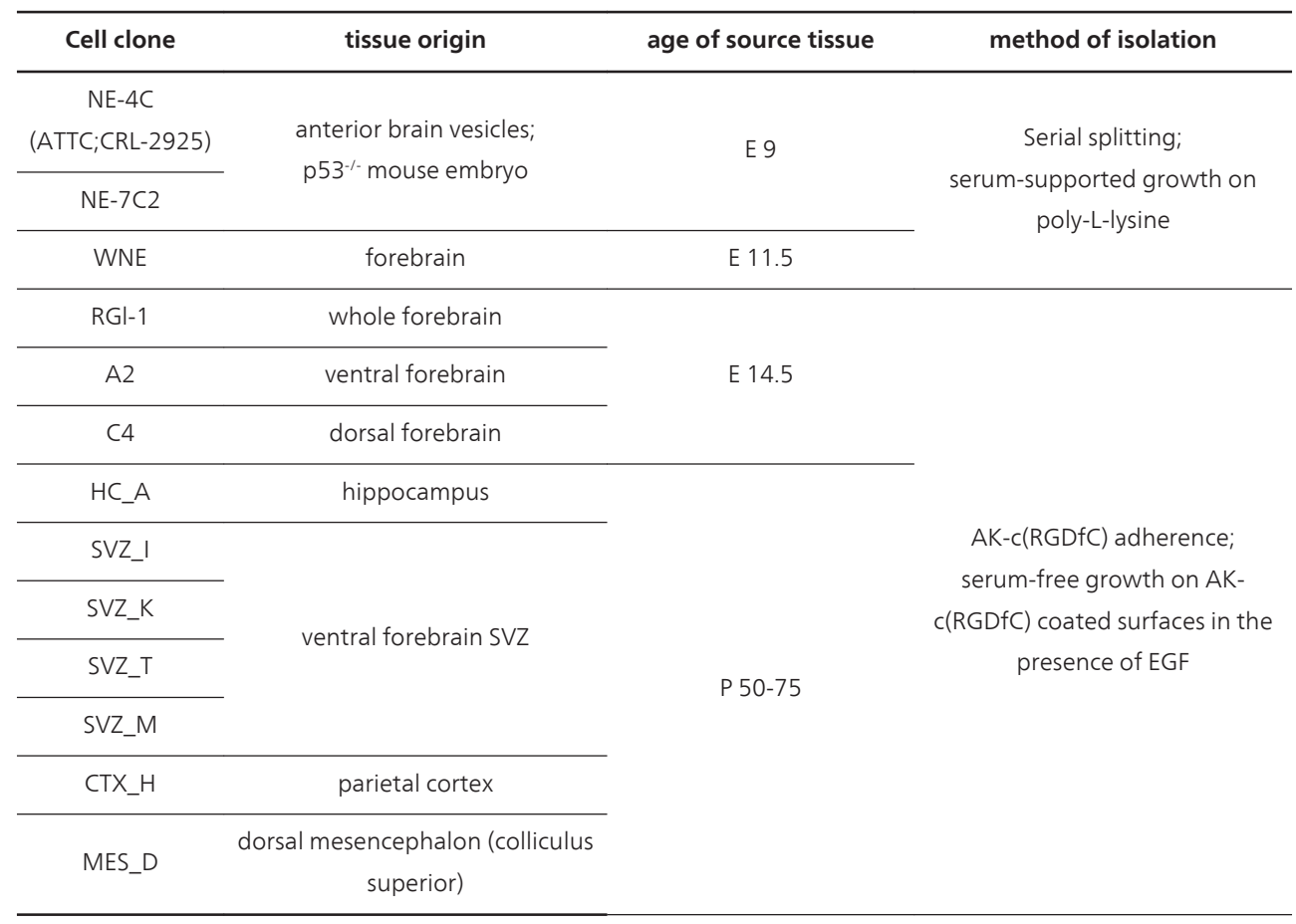

Table 2. Neural stem/progenitor clones investigated in the presented studies 
Multiple differences were found among the characterized cell lines indicating important diversity of neural cells, those fulfilling the criteria of "stemness".

\subsubsection{Morphological and cell biological characteristics of cloned stem/progenitor cell populations}

Early embryonic neuroectoderm-derived (NE-4C, NE-7C2 and WNE) cells display epithel morphology (Fig.6), and produce uniform monolayers. These cells divide continuously (16hour cycle-time in average) on poly-L-lysine in 10\% FCS containing medium, but can not be propagated in serum-free conditions on AK-c(RGDfC) coated surfaces. NE cells express nestin intermedier filamentum protein $[82,86]$ and two-third of the cells carries the mouse stem cell antigen, SSEA-1 [88]. In non-induced stage, the cells express Oct4, carry blbp and glast mRNAs (proteins could not be demonstrated), but do not express pax6, mash1 or neurogenins and do not produce GFAP and RC2 proteins [87].

In contrast to NE cells, embryo-derived AK-c(RGDfC)-adherent cells (RGl-1, A2, C4) proliferate on AK-c(RGDfC)-coated surfaces in serum-free, EGF $(20 \mathrm{ng} / \mathrm{ml})$ containing medium (cycletime: 18-20 hrs) (Fig.6). The cells show elongated morphology, display nestin, RC2 and Sox2 immunreactivity, but are immune-negative for GFAP. They transcribe large amount of blbp, glast, pax6, olig2 and also gfap mRNAs [74]. All clones express mash1, while neurogenin (ngn2) is not transcribed in the ventral forebrain-derived A2 clone. Oct4 or nanog expression was never detected. According to the above characteristics, these cells were identified as embryonic radial glia-like (eRGl) cells.

Adult-derived AK-c(RGDfC) adherent cells were prepared from the ventral forebrain SVZ (clones: SVZ_I, SVZ_K, SVZ_M, SVZ_T) from the hippocampus (HC_A), from the parietal cortex far from corpus callosum (CTX_H) and also from the dorsal midbrain parenchyma (colliculus superior), far from the wall of the ventricle (MES_D). As it was expected, AK-c(RGDfC) adherent cells were much less frequent in the adult brain-derived cell suspensions, than in the embryonic preparations. The selective adhesivity and EGFsupported proliferation, however, resulted in several clones from the adult mouse brain. Isolation of CTX_H and MES_D clones indicates that cells with stem/progenitor features are present in the non-neurogenic adult brain parenchyma at a frequency high enough to sort them out easily.

Regardless of origin, adult-derived clones display GFAP-, nestin- and RC2 immunpositivity, and carry immunocytochemically detectable Sox 2 and Pax6 proteins [74]. None of the cloned cells express Oct4 or nanog pluripotency genes. According to these features, the cells are regarded as adult-derived RGl cells (aRGl). Adult RGl cells grow in two dimensional clusters, where elongated cells line up along each other (Fig.6 right panel) and divide with a cycle-time of 20-22 hours in average. By today, eRGl and aRGl clones are over 50-80 passages without pheno- or genotypic changes; they preserved 2n (40 chromosome) euploidity, morphological features and neural inducibility. 

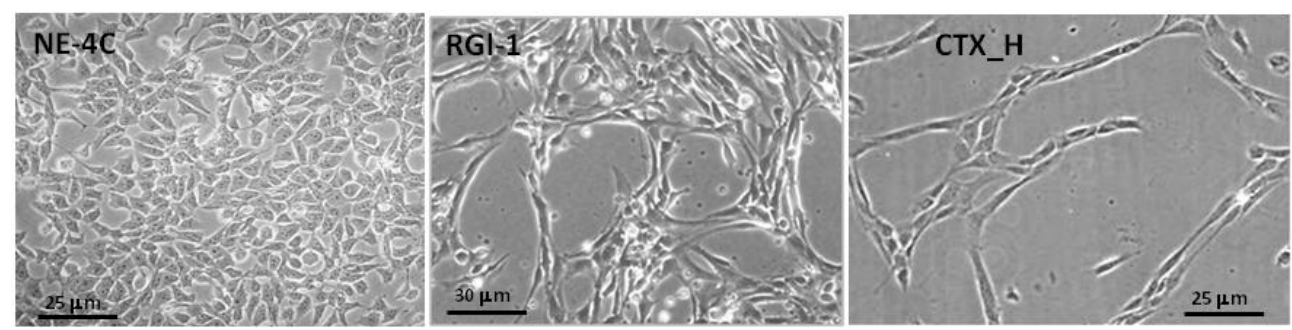

Figure 6. Phase-contrast view of NE-4C early embryonic neuroectodermal stem cells, the embryo-derived radial glia like RGI-1 cells and the adult cortex-derived CTX_H cells.

\begin{tabular}{|c|c|c|c|c|}
\hline & & $N E-4 C$ & RGI-1; A2 & HC_A; SVZ_M \\
\hline \multirow{4}{*}{ Cytochemical markers } & nestin & + & + & + \\
\hline & $\mathrm{RC} 2$ & - & + & + \\
\hline & GFAP & - & - & + \\
\hline & $\beta I I I-t u b$ & - & - & - \\
\hline \multirow{9}{*}{ Gene expression } & Oct 4 & + & - & - \\
\hline & Nanog & + & - & - \\
\hline & Sox2 & + & + & + \\
\hline & Pax6 & - & + & + \\
\hline & Blbp & + & + & + \\
\hline & GLAST & + & + & + \\
\hline & $\mathrm{Ngn} 2$ & - & + & + \\
\hline & Mash1 & - & + & + \\
\hline & Math2 & - & - & - \\
\hline \multicolumn{2}{|c|}{ Induction of neural differentiation } & \multicolumn{3}{|c|}{$\begin{array}{c}\text { EGF withdrawal (neurons); } \\
\text { serum (astrocytes); }\end{array}$} \\
\hline
\end{tabular}

Table 3. Similarities and differences between NE and RGI cells

Beside marked differences in shape, proliferation activity, pluripotency gene expression and GFAP and RC2 immunreactivity, RGl cells display different electrophysiological properties in comparison to early embryonic neuroectodermal (NE) cells. While both NE and RGl cells exist in multiple gap junction coupling, and consequently, display symmetric passive conductance in response to current injections [88], voltage-dependent K-currents $\left(\mathrm{K}_{\mathrm{DR}}\right)$ can be registered in RGl cells [74], but not in NE cells. 


\subsubsection{Generation of neural tissue-type cells by NE and RGl type neural stem/progenitor cells}

Studies on neuron and glia formation revealed further important differences between early embryonic neuroectoderm (NE) derived and embryonic or adult radial glia like stem/progenitor cells (Table 3).

Neural differentiation of NE cells is induced by retinoic acid (all-trans retinoic acid; RA; $\left.10^{-8}-10^{-6} \mathrm{M}\right)[82,86,89]$. A short (6-hour) RA treatment initiate aggregation of cells and the rate of aggregation increases at higher RA-concentrations and/or longer treatment. Forced aggregation of cells without RA, however, does not induce neural development, and, if initial aggregation is prevented, RA-treatment alone results in severe cell decay without differentiation [89]. It seems, that RA primes the cells for intercellular inductive signalling, what takes places inside RA-primed aggregates. After RA-priming, neural differentiation proceeds along an apparently stable program (Fig.7), in the absence of RA, in both serum-containing and serum-free culture conditions. RA-priming is required also for the formation of astrocytes from NE cells, even if glia genesis starts only 7-10 days after RA-priming [87].

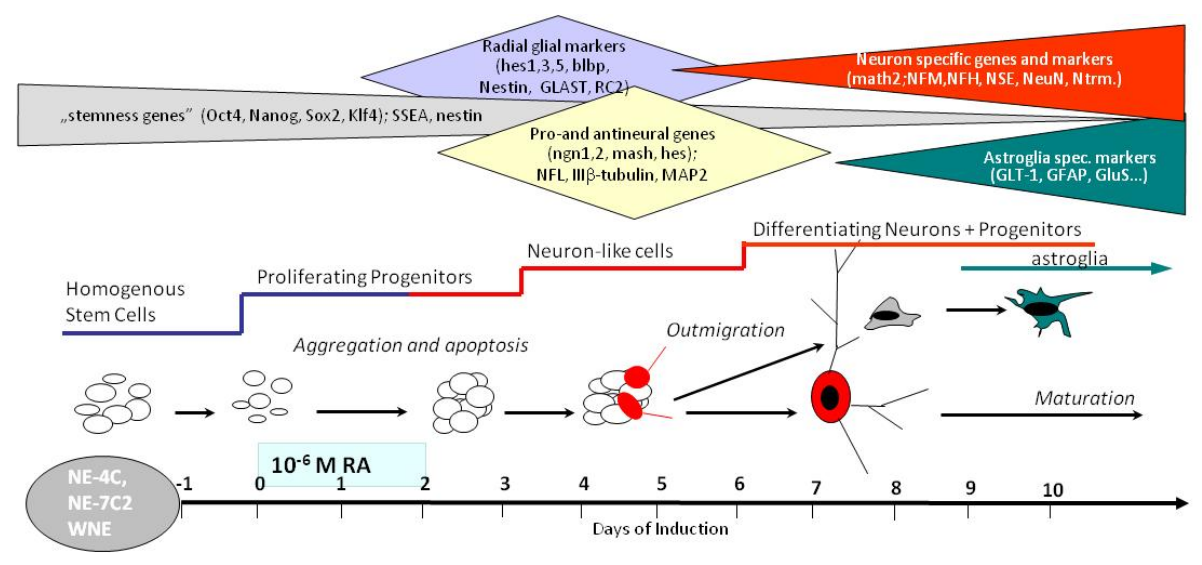

Figure 7. The scheme of RA-primed neural differentiation of NE cells.

20 hours after RA-priming, RC2 radial glia marker protein appears in the aggregated NE cells, and the first III $\beta$-tubulin- and MAP2-positive neuronal precursors appear on the $3^{\text {rd }}-4^{\text {rd }}$ day of induction, inside the aggregates. Expression of the proneural bHLH transcription factor $n g n 2$ is detected soon after induction (24-48 hours), increases during the first 5 days and decreases thereafter, when the "neuron-specific" math 2 transcription starts and increases gradually. The proportion of neurons reaches $50-55 \%$ of total cells during the second week of induction, and the first GFAP-positive cells appear around the $9^{\text {th }}$ day of induction. Nondifferentiated stem/progenitor cells persist during the entire period of neural differentiation as groups of SSEA-1 immunreactive epithelioid cells (Fig.8.) [33, 82, 87].

In contrast to NE cells, tissue-type differentiation of RGl cells is not induced by RA-treatment, regardless of the age and region of the source tissue [74, 90]. In RGl cells, neuronal differen- 

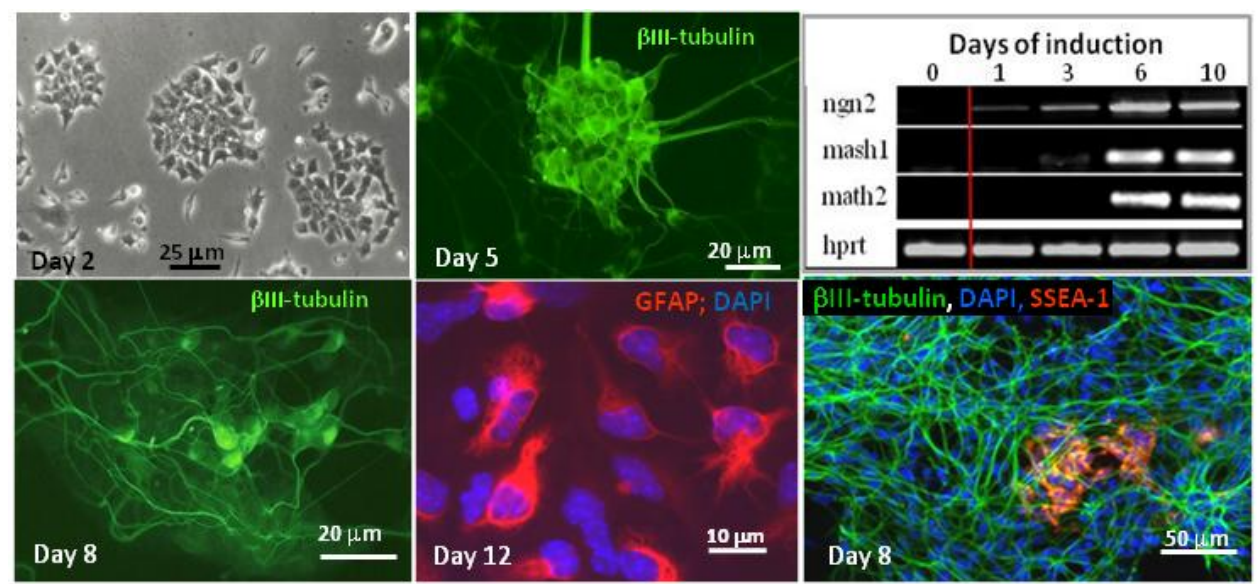

Figure 8. Immunocytochemical characterization of differentiating NE cells cells and the expression of some developmental neuronal "master" genes in the course of in vitro induced neural development. Developmental stages are indicated by days after RA-priming.

tiation is induced by withdrawal of EGF from the medium of dense cultures. Large-scale astroglia formation is initiated by adding serum (10\% FCS), and oligodendroglia production is achieved by treating the cells with FGF, PDGF and forskolin followed by treatment with thyroid hormone (T3) and ascorbic acid, according to the protocol of Glaser [91] (Fig.9.).

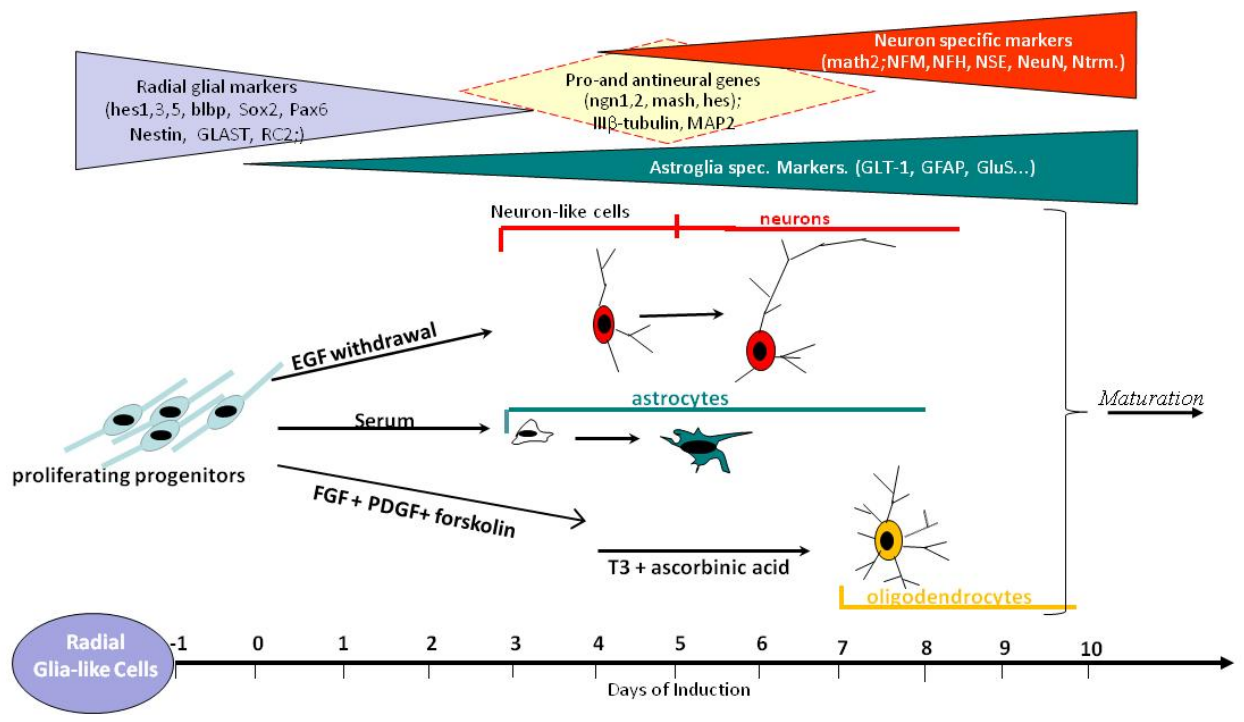

Figure 9. The scheme of in vitro neural tissue-type differentiation of RGI cells. 
Regardless of origin, RGl cells give rise to neurons in a 5-day period after withdrawal of EGF, to astrocytes in 3 days after treatment with serum, and to oligodendrocytes 8 days after the onset of oligodendroglia induction (Fig.9 and 10).
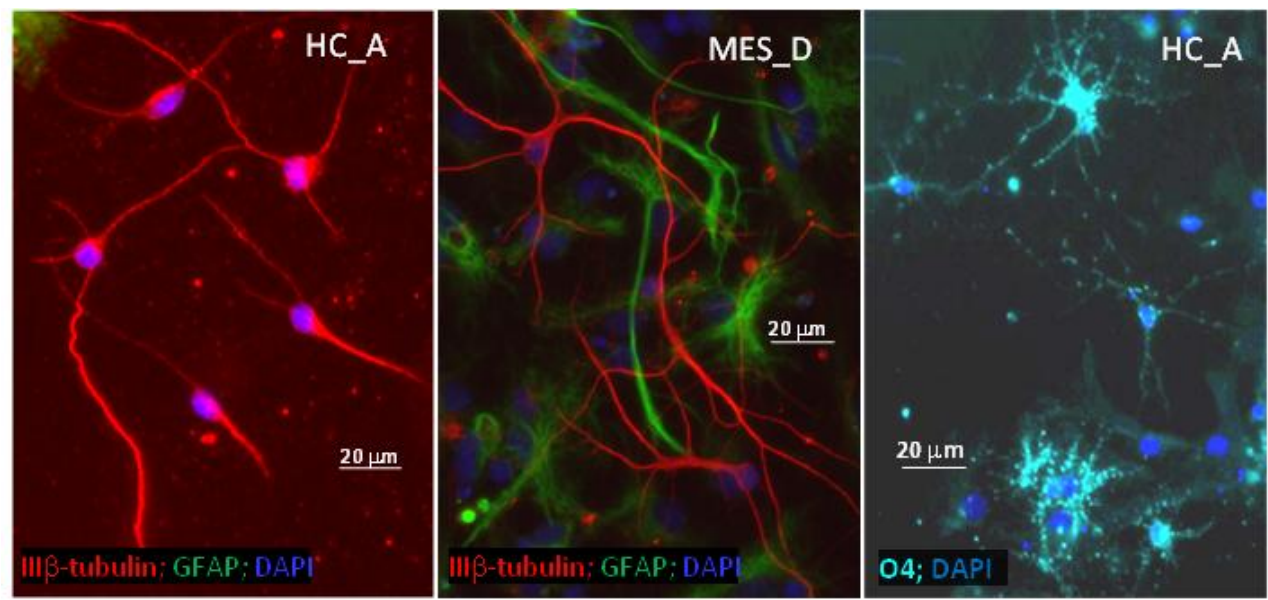

Figure 10. Neurons and oligodendrocytes generated by adult hippocampus- and mesencaphalon-derived (HC_A and MES_D) RGI cells are hown after neuron-specific III $\beta$-tubulin and oligodendroglia-indicating 04 immunostaining, respectively.

RGl cells generate neurons in smaller proportion than NE cells; the ratio of neurons among total cells does not exceed $20-30 \%$, and the yield varies among the different clones. Significant differences among the RGl clones were found also in the rate of oligodenroglia production [74]. The time-course of formation of "mature" phenotypes, however, is shorter in RGl cells than in NE cells.

\subsubsection{RA-production and $R A$-responsiveness of $N E$ and $R G l$ cells}

The retinoid-dependent and independent neuron formation is a striking difference between NE and RGl clones, respectively [90]. During development, RA regulates the formation of the neural tube and interferes with the patterning of the future hindbrain and spinal cord [92]. Important morphogenic roles of retinoids were demonstrated also in the developing forebrain [93], and the presence and production of RA were described in the developing lateral ganglionic eminence (LGE) [94,95]. RA-responsive cells persist in the main neural stem cell niches of the postnatal rodent brain including the SVZ and the dentate gyrus [96]. Depletion of RA in adult mice results in impaired neuronal differentiation in the dentate gyrus $[97,98]$ and RA synthesis seems to regulate proliferation and gene transcription of at least a subset of neural stem cells in the SVZ $[99,100]$. As retinoid signalling seems to influence the fate of neural stem cells throughout life, the fundamental differences in RA-responsiveness between NE and RGl type neural stem/progenitor cells have been investigated in details. 
Non-differentiated NE cells do not produce detectable retinoids [101], but differentiating daughter cells produce considerable amounts of RA [87, 90]. In contrast, RGl cells produce well-detectable amount of RA and retinoid production increases further with the advancement of neuronal differentiation. Endogenous RA production, on the other hand, does not influence the neuron formation by RGl cells: treatment with retinoic acid receptor (RAR) antagonist (AGN193109) does not result in significant changes in the number or morphology of RGlderived neurons [90]. Expression of genes coding components of the retinoid metabolism and signalling revealed significant differences between NE and RGl cells. NE and RGl cells express non-identical sets of retinaldehyde-dehydrogenases (RALDHs) and nuclear retinoid receptor subunits. Moreover, some defined retinoid transporters (as STRA6), and catabolising enzymes (as CYP26s) are not expressed by RGl cells [90]. In accordance with Haskell and LaMantia [99], we concluded that retinoid metabolism and responsiveness are distinctive characteristics of defined subtypes of neural stem/progenitor populations.

\subsection{4. "Regional memory"}

NE-4C cells, in non-induced "stem cell stage", express only otx 2 and en from the investigated "region-specific", positional genes. In differentiated NE-4C cultures, however, many positional genes including hoxb2 are actively transcribed (Table4) [33] indicating that these early embryonic stem cells are "open" for a variety of "position-determined" development. Accordingly, glutamatergic, GABAergic and also serotonin producing neurons develop from NE-4C cells.

Non-induced RGl cells, on the other hand, express $g b x 2$, $d l x 2$, em $x 2$, but not hoxb2 or $n k x 2.1$ (Table $4)$, regardless of origin. The pattern of investigated genes indicates an "anterior to hindbrain" (lack of active hoxb2), and a "not caudo-ventral" (lack of $n k x 2.1$ expression) origin, but does not distinguish between forebrain regions and between forebrain and mesencephalon derivatives.

\begin{tabular}{|c|c|c|c|c|c|c|c|c|c|c|c|}
\hline \multirow{3}{*}{$\begin{array}{l}\text { Clone } \\
\text { gene }\end{array}$} & \multirow{3}{*}{$\begin{array}{c}\text { NE } \\
N E-4 C\end{array}$} & \multicolumn{10}{|c|}{ RGI } \\
\hline & & \multicolumn{3}{|c|}{ Embryonic (E14.5) } & \multicolumn{7}{|c|}{ Adult (P 50-75) } \\
\hline & & A2 & C4 & RGI-1 & HC_A & CTX_H & MES_D & SVZ_I & SVZ_K & SVZ_T & $\overline{S V Z \_M}$ \\
\hline \multicolumn{12}{|c|}{ Gene expression } \\
\hline $\mathrm{Em} \times 2$ & - & + & + & + & + & + & + & + & + & + & + \\
\hline $\mathrm{Nkx2.1}$ & - & - & - & - & - & - & - & - & - & - & - \\
\hline Gbx2 & - & ni & ni & + & + & + & + & + & + & + & + \\
\hline Dlx2 & - & + & + & + & + & + & + & + & + & ni & ni \\
\hline Hoxb2 & - & ni & ni & - & - & - & - & - & - & ni & ni \\
\hline $\operatorname{Ngn} 2$ & - & - & + & + & + & + & + & + & - & + & + \\
\hline Mash1 & - & + & + & + & + & + & + & + & + & + & + \\
\hline
\end{tabular}

Table 4. Positional gene expression by non-induced stem/progenitor cells.

The neurotransmitter phenotype of neuronal progenies, on the other hand, still indicates preservation of some fine region-restricted commitment. All RGl cells give rise to GABAproducing, VGAT-positive neurons. In adult-derived clones, vesicular glutamate transporter 
(vglut) expression and VGLUT-immunpositivity [102] however was found only in the hippocampus-derived HC_A clone. As HC_A neurons express only vglut1 [74], it seems that these cells preserve some regional, neurotransmitter-related identity, even after long-term in vitro propagation. Similarly, all adult SVZ-derived clones give rise to tyrosin-hydroxylase(TH)expressing neurons [74]. This observation might be in accord with the known production of TH-positive olfactory neuron-precursors [103] in the adult SVZ.

The embryo-derived RGl-1 cells, on the other hand, express both, vglut1, vglut2 and also TH. The finding may indicate a less advanced stage of commitment of these cells, but needs further studies.

Available sporadic results do not allow deciding on the preservation or loss of regional identity of in vitro propagated stem/progenitor cells. As clones comprise progenies of single cells, for far-range conclusions we need further studies on statistically sufficient number of clones from each brain region.

\section{Distinct neural stem/progenitor stages require distinct environmental conditions}

One cell derived, cloned populations are useful subjects to show the types of cells which can or can not derive from a given stem cell population, but neither of such studies can predict what sort of phenotypes can be manifested in vivo. In the course of in vivo tissue genesis, differentiating cells and their environment change in an orchestrated way: the conditions either help tissue integration or kill the differentiating cells assuring the survival of the right types and number of cells at the right places.

In our experience, NE-4C cells give rise to neurons with large frequency if implanted into early embryonic brain vesicles, but produce non-differentiating, tumour-like expansions in the subcortical regions of newborn mice. Moreover, the same cells diminish from the adult mouse forebrain, except the forebrain SVZ, where some cells reside for longer than 3 weeks [104]. The data demonstrate that the fate of NE stem/progenitor cells is strictly governed by environmental factors provided by the host tissue, and which are far from being explored.

In addition to initial requirements for stem/progenitor survival, the successive progenies need different environment and change basic physiological demands including $\mathrm{O}_{2}$-supply [105; 77]. Under hypoxic conditions, NE-4C stem cells survive and proliferate, but do not generate neurons. Soon after the onset of in vitro neuronal differentiation (48 hrs after RA-priming), however, hypoxia severely impairs cell survival [105] indicating that the basic metabolic characteristics of cells change soon after neural fate decision. The in vitro results were supported by data obtained on the sporadic neuron formation by NE-4C cells implanted into the adult mouse forebrain in response to hyperbaric oxygenation [105]. 


\section{Conclusions}

The presented results on some selected NS populations demonstrate that neural stem/ progenitor cells derived from different brain regions and different ages may display significant diversity in many aspects including cell physiological and developmental features. The selected clones represent derivatives of a single stem cell and had been propagated under fairly artificial in vitro conditions; accordingly, none of them can represent "the" stem cells in general of the region of origin. From the data obtained on 3 different NE and 10 RGl cell clones, however, we could conclude that early embryonic neuroectoderm-derived stem cells display distinct in vitro features from those isolated by selective adhesion from later CNS tissues. In case of RGl cells, the adhesive preference-based selection and EGF-supported growth, imply a strong selection. Cells corresponding to such selection could be isolated from fairly distinct brain regions including areas not listed among "professional" neurogenic zones. Correspondingly, RGl cells may not represent a defined lineage of stem/progenitor population, rather a common stage of neural progenitor-succession, which may appear in many lineages. The integrin-based adhesion, EGF-supported proliferation, voltage-dependent $\mathrm{K}^{+}$-flux, RA-production and RAinsensitivity may be characteristics of stem/progenitor cells in a defined stage of tissue integration.

While many NS populations have been characterized in vitro [76], were implanted into different brain regions of healthy and disease-model animals and have been considered also as potential tools for clinical cell therapy (for critical review: [106, 107]), the basic physiology of such cells, their needs for survival in successive developmental stages as well as the harmonization of such needs with conditions provided by the host tissue are rarely taken into account. As a further task, physiological demands of various NS populations and descending progenies should be explored and the roles of basic physiological factors in tuning differentiation should be understood.

\section{Acknowledgements}

I thank my colleagues, especially to Zsuzsanna Környei and Károly Markó at the Cellular and Developmental Neurobiology Unit of IEM-HAS, and Katalin Schlett at the Dept. of Physiology and Neurobiology, Eötvös L. Univ., for common work, thinking and discussions. I wish to thank the Nikon Microscopy Center at IEM, Nikon Austria GmbH and Auro-Science Consulting Ltd for kindly providing microscopy support. I apologise to Authors whose excellent publications were not referred here because of space limitations. The presented studies were supported by National Science Foundation (OTKA) (K 68939, K106191), National Innovation Office (Bio_Surf) and Eu Fp6 (BioDot) grants. 


\title{
Author details
}

\author{
Emília Madarász
}

Institute of Experimental Medicin of Hungarian Academy of Sciences, Laboratory of Cellular and Developmental Neurobiology, Hungary

\section{References}

[1] Rakic P. Evolution of the neocortex: Perspective from developmental biology 2009. Nat Rev Neurosci., 10(10): 724-735

[2] Kriegstein A, Alvarez-Buylla A. 2009. The glial nature of embryonic and adult neural stem cells. Annu Rev. Neurosci 2009, 32:149-184.

[3] Albazerchi A., Stern C.D. 2007. A role for the hypoblast (AVE) in the initiation of neural induction, independent of its ability to position the primitive streak. Developmental Biology 301: 489-503

[4] Chapman SC, Schubert FR, Schoenwolf GC, Lumsden A. 2003. Anterior identity is established in chick epiblast by hypoblast and anterior definitive endoderm. Development;130:5091-5101

[5] Beddington, R. S. and Robertson, E. J. 1999. Axis development and early asymmetry in mammals. Cell 96,195 -209.

[6] Schoenwolf, G.C., 2001. Cutting, pasting and painting: experimental embryology and neural development. Nat. Rev. Neurosci. 2, 763-771.

[7] Shimamura K, Hartigan DJ, Martinez S, Puelles L, Rubenstein JL. 1995. Longitudinal organization of the anterior neural plate and neural tube. Development 121:3923-33

[8] Fietz S. A. and Huttner W.B. 2011. Cortical progenitor expansion, self-renewal and neurogenesis-a polarized perspective. Current Opinion in Neurobiology, 21:23-35

[9] Hemmati-Brivanlou A, Melton DA. 1994. Inhibition of activin receptor signaling promotes neuralization in Xenopus. Cell. 77: 273-81.

[10] Sidman RL, Rakic P. 1973. Neuronal migration with special reference to developing human brain: a review.. Brain Res., 62: 1-35.

[11] Artavanis-Tsakonas S, Rand MM, Lake RJ. 1999. Notch signaling: cell fate control and signal integration in development. Science 284: 770-776.

[12] Britsch S.The neuregulin-I/ErbB signaling system in development and disease. Adv Anat Embryol Cell Biol. 2007;190:1-65. 
[13] Gal JS, Morozov YM, Ayoub AE, Chatterjee M, Rakic P, Haydar TF. 2006. Molecular and morphological heterogeneity of neural precursors in the mouse neocortical proliferative zones. J.Neurosci. 26: 1045-56

[14] Jacobson M., 1978. Developmental Neurobiology. Plenum Press

[15] Sauer FC. 1935. Mitosis in the neural tube.. J.Comp.Neurol. 62: 377-405

[16] Hart A.H., Hartley L., Ibrahim M, Robb L. 2004. Identification, Cloning and Expression Analysis of the Pluripotency Promoting Nanog Genes in Mouse and Human. Devl.Dynamics 230:187-198

[17] Kimura C, Shen MM, Takeda N, Aizawa S, Matsuo I. 2001. Complementary functions of Otx2 and Cripto in initial patterning of mouse epiblast. Dev Biol 235:12-32.

[18] Acampora D, Gulisano M, Broccoli V, Simeone A. 2001. Otx genes in brain morphogenesis. Prog Neurobiol. 64(1):69-95.

[19] Klingensmith J, Ang S-L, Bachiller D, Rossant J. 1999. Neural Induction and Patterning in the Mouse in the Absence of the Node and Its Derivatives. Developmental Biology 216, 535-549

[20] Nakamura H, Katahira T, Matsunaga E, Sato T. 2005Isthmus organizer for midbrain and hindbrain development. Brain Res Brain Res Rev.; 49(2):120-6.

[21] Sasai Y. 1998. Identifying the missing links: genes that connect neural induction and primary neurogenesis in vertebrate embryos. Neuron. 21: 455-458

[22] Ellis P, Fagan M B, Magness S T, Hutton S, Taranova O, Hayashi S, McMahon A, Rao M. 2004. SOX2, a Persistent Marker for Multipotential Neural Stem Cells Derived from Embryonic Stem Cells, the Embryo or the Adult. Dev Neurosci, 26:148-165

[23] Callaerts P, Halder G, Gehring WJ. 1997. PAX-6 in development and evolution. Annu Rev Neurosci.;20:483-532.

[24] Götz M, Stoykova A, Gruss P. Pax6 controls radial glia differentiation in the cerebral cortex. Neuron. 1998;21:1031-1044.

[25] Kageyama R, Nakanishi S; 1997. Current Opinion in Genetics \& Development, 7:659-665

[26] Regan MR, Huang YH, Kim YS, Dykes-Hoberg MI, Jin L, Watkins AM, Bergles DE, Rothstein JD. Variations in promoter activity reveal a differential expression and physiology of glutamate transporters by glia in the developing and mature CNS. J Neurosci. 2007 Jun 20;27(25):6607-19.

[27] Liu R-Z, Mita R, Beaulieu M, Gao Z, Godbout R. Fatty acid binding proteins in brain development and disease. Int. J. Dev. Biol. 54: 1229-1239 (2010) doi: 10.1387/ijdb. 092976rl 
[28] Guillemot F., 2007. Spatial and temporal specification of neural fates by transcription factor codes. Development 134, 3771-3780

[29] Hébert JM, Fishell G. 2008. The genetics of early telencephalon patterning: some assembly required. Nat Rev Neurosci; 9(9):678-85.

[30] Puelles L, Rubenstein JL. 2003. Forebrain gene expression domains and the evolving prosomeric model. Trends Neurosci. 26(9):469-76.

[31] Kiecker and Lumsden 2012. The Role of Organizers in Patterning the Nervous System. Annu. Rev. Neurosci. 35:347-67.

[32] Onorati M, Binetti M, Conti L, Camnasio S, Calabrese G, Albieri I, Di Febo F, Toselli M, Biella G, Martynoga B, Guillemot F, Consalez GG, Cattaneo E. 2011. Preservation of positional identity in fetus-derived neural stem (NS) cells from different mouse central nervous system compartments. Cell Mol Life Sci. 68(10):1769-83.

[33] Varga B., Hadinger N, Gócza E., Dulberg V., Demeter K., Madarasz E.and Herberth B. 2008. Generation of diverse neuronal subtypes in cloned populations of stem-like cells. BMC Devl.Biol., 8: 89-107

[34] Hansen DV, Lui JH, Parker PR, Kriegstein AR, 2010. Neurogenic radial glia in the outer subventricular zone of human neocortex.Nature 2010, 464:554-561.

[35] Dhaliwal, J. and Lagace D. 2011. Visualization and genetic manipulation of adult neurogenesis using transgenic mice. Eur.J.Neurosci. 33: 1025-1036.

[36] García-Verdugo JM, Doetsch F, Wichterle H, Lim DA, Alvarez-Buylla A. 1998. Architecture and cell types of the adult subventricular zone: in search of the stem cells. J Neurobiol.; 36(2):234-48.

[37] Espinosa JS, Luo L. 2008. Timing neurogenesis and differentiation: insights from quantitative clonal analyses of cerebellar granule cells. J Neurosci. 28(10):2301-12.

[38] Kempermann G, Gage FH. 2000. Neurogenesis in the adult hippocampus.Novartis Found Symp.2000;231:220-235.

[39] Flames N, Pla R, Gelman D.M, Rubenstein J.L.R, Puelles L, Marın O. 2007. Delineation of Multiple Subpallial Progenitor Domains by the Combinatorial Expression of Transcriptional Codes. J. Neurosci., 27(36):9682-9695

[40] Anderson SA, Qiu M, Bulfone A, Eisenstat DD, Meneses J, Pedersen R, Rubenstein JLR. Mutations of the homeobox genes Dlx-1 and Dlx-2 disrupt the striatal subventricular zone and differentiation of late born striatal neuron. 1997. Neuron 19: 27-37.

[41] Anderson, SA., Mione, M., Yun, K., and Rubenstein, J. L. Differential origins of neocortical projection and local circuit neurons: role of Dlx genes in neocortical interneuronogenesis. 1999. Cereb Cortex 9: 646-54. 
[42] Bernier PJ, Bedard A, Vinet J, Levesque M, Parent A. 2002. Newly generated neurons in the amygdala and adjoining cortex of adult primates. Proc Natl Acad Sci U S A 99:11464-11469.

[43] Marchis S, Fasolo A, Puche A.C. 2004. Subventricular Zone-Derived Neuronal Progenitors Migrate into the Subcortical Forebrain of Postnatal Mice. J. Comp. Neurol. 476:290-300

[44] Letinic K, Rakic P. 2001. Telencephalic origin of human thalamic GABAergic neurons. Nature Neurosci.;4:931-936.

[45] Richardson W.D, Kessaris N., Pringle N. 2006. Oligodendrocyte wars Nat. Rev. Neurosci. $7: 11-18$

[46] Gonzalez-Perez O, Alvarez-Buylla A. 2011. Oligodendrogenesis in the subventricular zone and the role of epidermal growth factor. Brain Res Rev. 67(1-2):147-56.

[47] Donkelaar H. J. Lammens M., Wesseling P., Thijssen H. O. M., Renier W. O. 2003. Development and developmental disorders of the human cerebellum. J Neurol., 250 : 1025-1036

[48] Altman, J. and Bayer, S. A. 1990. Mosaic organization of the hippocampal neuroepithelium and the multiple germinal sources of dentate granule cells. J. Comp. Neurol. $301,325-342$.

[49] Galceran J, Miyashita-Lin E.M., Devaney E, John L. R. RubensteinJ.L.R, Grosschedl R. 2000. Hippocampus development and generation of dentate gyrus granule cells is regulated by LEF1. Development 127, 469-482

[50] Doetsch F, Garcia-Verdugo JM, Alvarez-Buylla A. Cellular composition and three-dimensional organization of the subventricular germinal zone in the adult mammalian brain. 1997. J.Neurosci., 17: 5046-5061.

[51] Zhao C, Teng EM, Summers RG Jr, Ming GL, Gage FH. 2006. Distinct Morphological Stages of Dentate Granule Neuron Maturation in the Adult Mouse HippocampusJ. Neurosci., 26(1):3-11

[52] Paton JA, Nottebohm FN. Neurons generated in the adult brain are recruited into functional circuits. Science. 1984;225(4666):1046-8.

[53] Lledo P.M., Alonso M, Grubb M.S, Adult neurogenesis and functional plasticityin neuronal circuits. Nat.Rev.Neurosci. 2006. 7: 179-193

[54] Gould E, Reeves A.J., Graziano M.S.A.,. Gross C. G. 1999. Neurogenesis in the Neocortex of Adult Primates. Science, 286: 548-552

[55] Bedard A, Levesque M, Bernier PJ, Parent A. 2002. The rostral migratory stream in adult squirrel monkeys: contribution of new neurons to the olfactory tubercle and involvement of the antiapoptotic protein Bcl-2. Eur J Neurosci 16:1917-1924. 
[56] Hodge R.D., Thomas D. KowalczykT.D, Wolf S.A., Encinas J.M., Rippey C., Enikolopov G., Kempermann G., Hevner R.F.; 2008. Intermediate Progenitors in Adult Hippocampal Neurogenesis: Tbr2 Expression and Coordinate Regulation of Neuronal Output. J. Neurosci. 28(14): 3707-3717

[57] Li L, Clevers H. 2010. Coexistence of Quiescent and Active Adult Stem Cells in mammals. Science: 327 (5965): 542-545

[58] Lois C., Garcia-Verdugo J.M., Alvarez-Buylla, A.; 1996. Chain migration of neuronal precursors. Science 271: 978-981

[59] Zhao Ch, W. Deng, Gage F. (2008). Mechanisms and Functional Implications of Adult Neurogenesis. Cell 132: 645-660

[60] Marín-Burgin A, Mongiat L, Pardi M.B., Schinder A. F. (2012) Unique Processing During a Period of High Excitation/Inhibition Balance in Adult-Born Neurons. Science; 335(6073): 1238-1242

[61] Alonso M, Lepousez G, Sebastien W, Bardy C, Gabellec MM, Torquet N, Lledo PM. 2012. Activation of adult-born neurons facilitates learning and memory. Nat Neurosci. 2012 Jun;15(6):897-904.

[62] Fowler C.D., Liu Y., Wang Z. Estrogen and adult neurogenesis in the amygdala and hypothalamus. Brain Res Rev. 2008 March ; 57(2): 342-351.

[63] Collin T, Arvidsson A, Kokaia Z, Lindvall O. 2005. Quantitative analysis of the generation of different striatal neuronal subtypes in the adult brain following excitotoxic injury. Exp Neurol. 195(1):71-80.

[64] Migaud M, Batailler M, Segura S, Duittoz A, Franceschini I, Pillon D. 2010. Emerging new sites for adult neurogenesis in the mammalian brain: a comparative study between the hypothalamus and the classical neurogenic zones. Eur J Neurosci. 32(12): 2042-52.

[65] Bonfanti L, Nacher J., 2012. New scenarios for neuronal structural plasticity in nonneurogenic brain parenchyma: the case of cortical layer II immature neurons. Prog Neurobiol. 98(1):1-15.

[66] Geraerts M, Krylyshkina O, Debyser Z, Baekelandt V., 2007. Concise review: therapeutic strategies for Parkinson disease based on the modulation of adult neurogenesis. Stem Cells. 25(2):263-70.

[67] Baumann N., Pham-Dinh D. 2001. Biology of Oligodendrocyte and Myelin in the Mammalian Central Nervous System. Phys. Rev. 81: 871-927

[68] Meletis K, Barnabe-Heider F, Carlen M, Evergren E, Tomilin N, Shupliakov O, Frisen J. Spinal cord injury reveals multilineage differentiation of ependymal cells. PLoS Biol 6:e182, 2008. 
[69] Raff MC, Miller RH, Noble M., 1983. A glial progenitor cell that develops in vitro into an astrocyte or an oligodendrocyte depending on culture medium. Nature. 303(5916): 390-396.

[70] Franklin R J. M. and Charles ffrench-Constant 2008. Remyelination in the CNS: from biology to therapy. Nat.Rev.Neurosci. 9(11):839-55

[71] Robel S, Berninger B, Gotz M. 2011. The stem cell potential of glia: lessons from reactive gliosis. Nat Rev Neurosci 12: 88-104,

[72] Ohira, K., 2011. Injury-induced neurogenesis in the mammalian forebrain. Cell Mol Life Sci. 68(10):1645-56.

[73] Decimo I., Bifari F., Krampera M., Fumagalli G. 2012. Neural stem cell niches in health and diseases. Curr. Pharm. Design 18: 1755-1783.

[74] Marko K, Kohidi T, Hadinger N, Jelitai M, Mezo G, Madarasz E. 2011. Isolation of radial glia-like neural stem cells from fetal and adult mouse forebrain via selective adhesion to a novel adhesive peptide-conjugate. PlosOne; I www.plosone.org 6 | 12 | e28538

[75] Ming,G. and Song H., 2011. Adult neurogenesis in the mammalian brain: Significant aswers and significant questions. Neuron 70: 687-702.

[76] Conti L., Cattaneo E.,2010. Neural stem cell systems: physiological players or in vitro entities? Nat.Rev.Neurosci. 11: 176-187

[77] Crossin, K., 2012. Oxygen levels and the regulation of cell adhesion in the nervous system: A control point for morphogenesis in development, disease and evolution? Cell Adh., Migr. 6 (1): 49-58.

[78] Chen J, Herrup K., 2008. Selective vulnerability of neurons in primary cultures and in neurodegenerative diseases. Rev Neurosci. 2008;19(4-5):317-26.

[79] Juurlink BH, Hertz L.1985. Plasticity of astrocytes in primary cultures: an experimental tool and a reason for methodological caution. Dev Neurosci.; 7(5-6):263-77.

[80] Madarász E, Kiss J, Bartók I. 1984. Cell production and morphological pattern formation in primary brain cell cultures. I. Pattern formation within the basal layer(s). Brain Res. 304: 339-349

[81] Madarász E, Theodosis DT, Poulain DA. 1991. In vitro formation of type 2 astrocytes derived from postnatal rat hypothalamus or cerebral cortex. Neuroscience. 43: 211-221.

[82] Schlett K, Madarasz E. 1997. Retinoic acid induced neural differentiation in a neuroectodermal cell line immortalized by p53 deficiency. J Neurosci Res. 47: 405-415. 
[83] Livingstone L.R., White A., Sprouse J., Livanos E., Jacks T., Tisty T.D. Altered cell cycle arrest and gene amplification potential acoompany loss of wild-type p53. 1992. Cell, 70: 923-935.

[84] Marko K., Ligeti M., Mezo G., Mihala K., Kutnyinszky E., Kiss E., Hudecz F., Madarasz E. 2008. A novel synthetic peptide polymer with cyclic RGD motifs supports serum-free attachment of anchorage-dependent cells. Bioconjugate Chemistry 19: $1757-1766$

[85] Nolte C, Matyash M, Pivneva T, Schipke CG, Ohlemeyer C, et al. (2001) GFAP promoter-controlled EGFP-expressing transgenic mice: a tool to visualize astrocytes and astrogliosis in living brain tissue. Glia 33: 72-86.

[86] Varju,P., Schlett,K. Eisel,U., Madarász,E. Schedule of NMDA receptor subunit expression and functional channel formation in the course of in vitro induced neurogenesis. J.Neurochem. 2001. 77, 1444-1456

[87] Hádinger N, Varga B.v, Berzsenyi S, Környei Zs, Madarasz E, Herberth B. 2009. Retinoic acid regulates astrogliogenesis. Int.J.Devl.Neurosci. 27: 365-375

[88] Jelitai M., Anderova M., Chvatal A., Madarasz E., 2007.Electrophysiological characterization of neural stem/progenitor cells during in vitro differentiation: a study on an immortalized neuroectodermal cell line. J.Neurosci.Res. 85(8):1606-1617

[89] Tarnok K., Pataki A., Kovacs J., Schlett K., Madarasz E., 2002. Stage -dependent effects of cell-to cell connections on in vitro induced neurogenesis. Eur.J.Cell Biol.,. 81 (7): 403-412

[90] Orsolits B, Borsy A, Madarász E, Mészáros Z, Kőhidi T, Markó K, Jelitai M, Welker E, Környei Z. Retinoid machinery in distinct neural stem cell populations with different retinoid responsiveness. Stem Cell Devl. 2013 in press

[91] Glaser T, Pollard SM, Smith A, Brustle O (2007) Tripotential differentiation of adherently expandable neural stem (NS) cells. PLoS One 2: e298.

[92] Maden M. 2006. Retinoids and spinal cord development. J Neurobiol 66:726-38.

[93] Halilagic A, V Ribes, NB Ghyselinck, MH Zile, P Dolle and M Studer. (2007). Retinoids control anterior and dorsal properties in the developing forebrain. Developmental biology 303:362-75.

[94] Toresson H, A Mata de Urquiza, C Fagerstrom, T Perlmann and K Campbell. 1999. Retinoids are produced by glia in the lateral ganglionic eminence and regulate striatal neuron differentiation. Development 126:1317-26

[95] Chatzi C, T Brade and G Duester. 2011. Retinoic acid functions as a key GABAergic differentiation signal in the basal ganglia. PLoS Biol 9:e1000609. 
[96] Wagner E, T Luo, Y Sakai, LF Parada and UC Drager. 2006. Retinoic acid delineates the topography of neuronal plasticity in postnatal cerebral cortex. The European journal of neuroscience 24:329-40.

[97] Bonnet E, K Touyarot, S Alfos, V Pallet, P Higueret and DN Abrous. 2008. Retinoic acid restores adult hippocampal neurogenesis and reverses spatial memory deficit in vitamin A deprived rats. PLoS One 3:e3487.

[98] Jacobs S, DC Lie, KL DeCicco, Y Shi, LM DeLuca, FH Gage and RM Evans. 2006. Retinoic acid is required early during adult neurogenesis in the dentate gyrus. Proc Natl Acad Sci U S A 103:3902-7.

[99] Haskell GT and AS LaMantia. 2005. Retinoic acid signaling identifies a distinct precursor population in the developing and adult forebrain. J Neurosci 25:7636-47.

[100] Wang TW, H Zhang and JM Parent. 2005. Retinoic acid regulates postnatal neurogenesis in the murine subventricular zone-olfactory bulb pathway. Development 132:2721-32.

[101] Kornyei Z, E Gocza, R Ruhl, B Orsolits, E Voros, B Szabo, B Vagovits and E Madarasz. 2007. Astroglia-derived retinoic acid is a key factor in glia-induced neurogenesis. FASEB J 21:2496-509.

[102] Fremeau RT, Jr., Troyer MD, Pahner I, Nygaard GO, Tran CH, et al. 2001. The expression of vesicular glutamate transporters defines two classes of excitatory synapse. Neuron 31: 247-260.

[103] Pignatelli A, Ackman JB, Vigetti D, Beltrami AP, Zucchini S, Belluzzi O (2009) A potential reservoir of immature dopaminergic replacement neurons in the adult mammalian olfactory bulb. Pflugers Arch 457(4):899-915.

[104] Demeter K, Herberth B, Duda E, Kúsz E, Jaffredo T, Herman J.-P, Madarász E. 2004. Fate of neuroectodermal cells implanted into the adult, newborn or embryonic brain. Exp.Neurol. 188(2):254-267

[105] Zadori A., Agoston V.A., Demeter K., Hadinger N., Varady L., Kohídi T, Gobl A., Nagy Z, Madarász E. 2011. Survival and differentiation of neural stem cells at different oxygen levels. Exp.Neurology 227, (1): 136-148

[106] Chiu A Y and Rao M.S. 2011. Cell-Based Therapy for Neural Disorders - Anticipating Challenges. Neurotherapeutics 8:744-752

[107] Lindvall O and Björklund A. 2011. Cell Therapeutics in Parkinson's Disease. Neurotherapeutics 8:539-548 